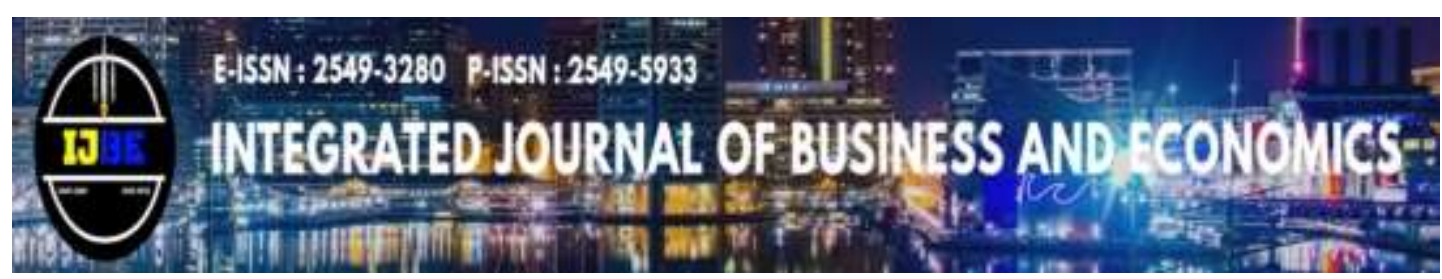

Email: ijbe.feubb@gmail.com

Laman: http://ojs.ijbe-research.com/index.php/IJBE/index

\title{
Existence Of Company Size In Control Towards Family Ownership And Debt Policy Value Of Companies
}

\author{
Murtiadi Awaluddin ${ }^{\mathrm{a}}$, Alim Sholihin ${ }^{\mathrm{b}}$, Sumarlin ${ }^{\mathrm{c}}$, Rulyanti Susi Wardhani ${ }^{\mathrm{d}}$, Andi \\ Sylvana ${ }^{\mathrm{e}}$ \\ ${ }^{a, b, c}$ UIN Alauddin Makassar, Indonesia \\ ${ }^{d}$ Universitas Bangka Belitung, Indonesia \\ ${ }^{e}$ Open University, Indonesia \\ murtiadi.awaluddin@uin-alauddin.ac.id
}

\begin{abstract}
This study aims to examine the effect of family ownership, debt policy on firm value with firm size as a control variable. The sample used was a family company listed on the Indonesia Stock Exchange from 2014 to December 2017. The type of this research was quantitative using Agency theory and Signaling Theory. Analysis technique with multiple regression analysis. The results showed that family ownership had a positive and significant effect on firm value, and debt policy had a negative and significant effect on firm value. While company size as a control variable in this study cannot control the relationship of the influence of family ownership and debt policy on firm value, in other words, company size as a control variable does not have a significant effect on the relationship of family ownership and corporate value policy debt.
\end{abstract}

\section{Article Info}

- Received : April 25, 2020

- Revised : May 8, 2020

- Published : June 12, 2020

- No. Pages : 133 - 146

- DOI : 10.33019/ijbe.v4i2.267

- JEL : H63, G32

- Keywords : Family Ownership, Debt Policy, Company Size, and Company Value. 


\section{Introduction}

Generally, the main reason for the formation or establishment of a company is to increase shareholder income. Every shareholder of a company and as a company owner always expects the company to have more value. Because the prosperity of shareholders can be seen from the value of the company (Nurhayati, 2013). When the value of the company is maximized broadly it means maximizing profits as well. This condition will consider the effect of time on money, as well as consider various risks to income and the presence of cash flowing in the future. Escalation of the value of companies is a long-term goal that is required by the company. Such increase in the price of the stock market, making investors to the company can be seen from the movement of shares of the company for the companies that go public.. But often the value of a company or a company's stock price fluctuates within a certain period. This is caused by both internal and external factors of the company.

Regarding companies, the majority of companies in Indonesia are dominated by family companies. On several news sites that discuss family companies in Indonesia, including https://www.cnnindonesia.com states that a survey conducted by companies audited from the United States found that 95 percent of companies in Indonesia are family companies. The results obtained are known that 40,000 rich people in Indonesia, or about 0.2 percent of the total population who run a family business with total wealth of $\mathrm{Rp} 135$ trillion or around 25 percent of gross domestic product (GDP) in Indonesia, are family businesses.

A company can be said as a family company when the family has a minimum of 50 percent shareholdings in the company (Harahap \& Wardhani, 2011). The decision to use $50 \%$ ownership is because it is considered to have given a significant rating limit to have effective control on the company. Family companies have their own uniqueness that makes the company more effective than non-family companies. The uniqueness in family companies such as CEO tends to be wiser because the CEO is also the owner of the company so that there is an increase in profitability (Litz, Pearson, \& Litchfield, 2012). Another uniqueness of the family company is having knowledge about the company so that it can carry out more effective monitoring (N.A. \& Che-Ahmad, 2010). There is a plural phenomenon in the family company is that the founder has a focus on hard work so that the company can grow and survive. In the next development, when the company started to grow bigger and stronger, the second generation and extended family, including brothers, nieces and grandchildren began to enter, even becoming the dynasty of family.

According to Barney (1991) corporate control provides several advantages, namely the family company has a competitive advantage which ultimately causes the creation of stability and focus on long-term benefits. This is done so that the company can still be run and survive to remain bequeathed to the next generation in the family. If the results of the company's operations provide a large profit to the company, automatically the company's value or the stock price of the company will rise. 
Debt policy is company policy about the importance of using the company and for its obligations (Yuniati, Raharjo, \& Abrar, 2016). In reality, companies are required to determine the optimal capital structure policy because basically funding sources have an impact on the value of the company (Butje, Pahlevi, \& Pakki, 2019). The capital structure is the composition of own funding (equity) and debt. The higher the proportion of debt, the higher the share price, but at some point, an increase in debt will reduce the value of the company because the benefits derived from the use of debt are smaller than the costs incurred (Herawati, 2013). Companies with favourable prospects will try to avoid selling shares and seeking new capital using debt. Managers can use more debt, which later acts as a more reliable signal because companies that increase debt can be seen as companies that are confident in the company's prospects in the future (Warapsari \& Suaryana, 2016). Investors are expected to catch the signal, which is a signal that the company has a prospective or high value for money in the future. So, it can be concluded that debt is a positive signal from the company.

Table 1. Average Price to Book Value (PBV) and Debt Equity Ratio (DER) Family Companies Listed on the Jakarta Stock Exchange 2013 - January 2017

\begin{tabular}{|c|c|c|c|c|c|c|}
\hline \multirow[t]{2}{*}{ No } & \multirow[t]{2}{*}{ Ratio } & \multicolumn{5}{|c|}{ Tahun } \\
\hline & & 2013 & 2014 & 2015 & 2016 & $\begin{array}{l}\text { January- } \\
2017 \\
\end{array}$ \\
\hline 1 & Price to Book Value (PBV) & 4.48 & 5.26 & 4,79 & 5.60 & 5.50 \\
\hline 2 & Debt to Equity Ratio (DER) & 0.48 & 0.60 & 0.66 & 0.62 & 0.58 \\
\hline
\end{tabular}

Source: BEI, 2019

Information regarding debt policy and company value in family companies listed on the Indonesia Stock Exchange (IDX) has fluctuated, resulting in reduced investor confidence. This is based on empirical data on Price to Book Value (PBV) and Dept. Equity Ratio (DER) of family companies listed on the IDX. The following is the overall average sample of companies from 2014 - January 2017.

Based on Table 1 above which shows the phenomenon that is vulnerable in 2013 to January 2017 the value of the company is measured by PBV (Price to Book Value) in a company experiences ups and downs or fluctuates. This phenomenon has an impact on investor confidence, smart investors will automatically rethink and consider carefully to invest their capital in a company that is experiencing fluctuations in the value of the company. One of the causes of company value fluctuates or fluctuates is debt that is used as a funding option in a company that if the results of the use of the company's funds benefit, the company's value will also increase otherwise if the results of the use of debt as a funding for the company's operations get a loss then automatically the value of the company will also go down and of course investors will also be reluctant to invest in the company. 


\section{Literature Review}

Agency theory is a theory that explains the relationship between principals and agents in a company. Where the principal is a shareholder in a company or can be said to be the owner of the company while the agent who has the obligation to maximize the welfare of shareholders is a manager in a company that is incorporated in the management of the company (Jensen \& Meckling, 1976). As the phenomenon of corporate ownership spreads and the occurrence of diversification of ownership results in separate ownership and management. This separation causes problems because there are two interests, namely between owners and management which are not always in line (Harahap \& Wardhani, 2011). Pooling of interests like this, often cause conflicts called agency conflicts (Jensen \& Meckling, 1976). The transition in the business environment resulted in a company that was once only owned by one person, the owner-manager is now a company whose ownership is spread with shareholders owned by various groups.

\section{Signaling Theory}

Judging from the signaling theory, there is a stock reaction if there is an increase or decrease in corporate debt. In general, funding using debt is a positive signal. Because the company has an opportunity for profitable investment, the company will need additional funds to meet the company's investment plan. Therefore, some companies use debt to fund the company's operations. Therefore, investors view companies that increase the proportion of debt is a company that has good company prospects and automatically when the company is seen as having good prospects, the company's stock price will increase and directly the company's value will also increase (Connelly, Certo, Ireland, \& Reutzel, 2011).

According to Brigham \& Houston (2014), Funding using debt to companies that have good prospects in the future will provide very good benefits to existing companies and investors. Funding using debt is better than having to sell new shares to investors when the company has very good prospects in the future, but vice versa when the company has bad prospects in the future, the company should sell new shares to investors. losses received by the company due to bad prospects will share losses with new investors.

\section{The value of the company}

Value companies are certain conditions that have been achieved by a company as an overview of public confidence in the company (Pasaribu, Nuryartono, \& Andati, 2019). Community compares with purchase company stock at a price according to the perceived beliefs. This is consistent with that proposed by Harmono (2011) that the value of the company is reflected in the performance of the company's stock price due to market demand and supply of capital.

According to Fakhruddin \& Sopian (2001), the ratio that shows whether the price of traded shares is overvalued (above) or undervalued (below) the book value of shares 
is called Price to book value (PBV). PBV illustrates how much the market appreciates the book value of a company's shares. The higher the ratio, the market believes the company's prospects. PBV shows how far a company can create corporate value relative to the amount of capital invested. The formulas used to measure company value are:

$$
P B V=\frac{\text { Market price per share }}{\text { Book Value per share }}
$$

\section{Ownership Structure}

The theory of corporate management, which is increasingly separated from company ownership, is one of the characteristics of a modern economy. This is an agency theory that wants company owners (principle) to hand over company management to more professional staff who are more understanding in doing business. The purpose of control and company ownership is separated so that the owner gains maximum profit with efficient costs. Demsetz \& Lehn (2009), explains that the successful implementation of corporate governance is inseparable from the structure of corporate ownership. The ownership structure is reflected both through the stock instrument and the debt instrument so that through this structure, it can be seen the possibility of agency problems that will occur.

A family company is a company whose ownership is owned by the family. Companies owned by a family generally will put their family members in the position of CEO, commissioner, or other management positions. Companies with family ownership constitute the majority of types of companies in Indonesia. These companies are generally majority-owned by certain families, or share ownership is concentrated in certain families (Beuren, Politelo, \& Martins, 2016).

A company can be said to be a family company if family ownership in the company is at least $50 \%$ that must be owned by the family (Harahap \& Wardhani, 2011). The decision to use $50 \%$ ownership is because it is considered to have given a significant rating limit to have effective control of the company. Even though the family business grows as a public company, the control is still held by the family.

\section{Debt Policy}

Debt policy is a company policy about how far a company uses debt funding (Mardiyati, Gatot, \& Ria, 2012). In reality, companies are required to determine the optimal capital structure policy because, basically, funding sources have an impact on the value of the company (Meythi, 2012). Capital structure is the composition of its own funding (equity) and debt. The higher the proportion of debt, the higher the share price, but at some point, an increase in debt will reduce the value of the company because the benefits derived from the use of debt are smaller than the costs incurred (Yuniati et al., 2016). In making decisions about the use of debt the company must consider the fixed costs that arise in the form of interest (Wardhani, Awaluddin, \& Reniati, 2019). 


\section{Company Size}

The size of the company is a scale that can be classified on the size of companies according to various ways such as by total assets, log size, the value of the stock market, and others (Fitri Prasetyorini, 2013). Meanwhile, according to Rizqia, Dwita, Siti, \& Sumiati (2013), the company's size is the level to show the company's development in business. The size of the company will affect the ability to bear the risks that may arise from various situations facing the company. The size of the company also determines the level of investor confidence. Habbash (2016) states that the larger a company is, the more stakeholders will highlight it. For companies that have been large and have large enough total assets will be in the lyrics of investors to invest their capital in these companies.

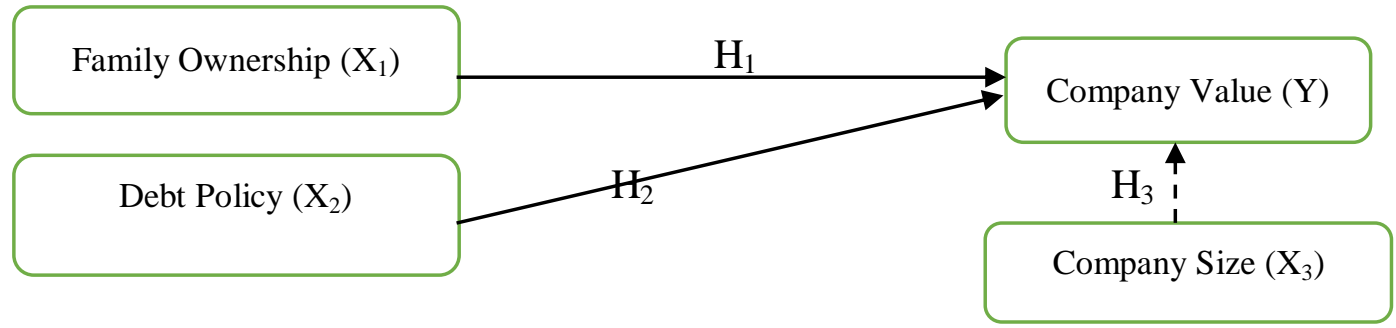

Figure 1. Framework for Thinking

\section{Research Methods}

Research conducted quantitative research, using secondary data. The population is all of the financial statements of companies listed on the IDX in the period 2014 to 2017. The target population is family companies listed on the IDX in the period 2014 to 2017. Determination of the sample in this study is to use purposive sampling with sample criteria of 10 family companies $10 \times 4$ (years) $=40$ data.

The analysis technique is descriptive statistical analysis, classic assumption test and multiple regression analysis, $t$ test and coefficient of determination by conducting two tests using the control variable. Where testing is done using a control variable and without using a control variable.

\section{Results and Discussion}

Descriptive analysis is used to describe research-related data that is indicated by the average value, standard deviation, maximum, and minimum.

Table 2. Descriptive Statistics Analysis Results

\begin{tabular}{|l|r|r|r|r|r|}
\hline \hline & \multicolumn{1}{|c|}{$\mathrm{N}$} & \multicolumn{1}{c|}{ Minimum } & \multicolumn{1}{c|}{ Maximum } & \multicolumn{1}{|c|}{ Mean } & Std. Deviation \\
\hline PBV & 40 & .12 & 9.30 & 2.4055 & 2.13789 \\
FO & 40 & 50.37 & 96.52 & 68.5500 & 12.21939 \\
DER & 40 & .22 & 3.73 & 1.1423 & .87885 \\
SIZE & 40 & 6.71 & 7.96 & 7.2795 & .36555 \\
Valid N & 40 & & & & \\
(listwise) & & & & & \\
\hline
\end{tabular}

Source: Data processed, 2020 
Based on Table 2 shows that Family Ownership has a value between 50.37-96.52 with an average cost of 68.5500 and a standard deviation of 12.21939. While the family company debt policy calculated by DER has a value between $0.22-3.73$ with an average value of 1.1423 and a standard deviation of 0.87885 . And the size of the company as a control variable has a value between 6.71-7.96 with an average cost of 7.2795 and a standard deviation of 0.365555 . The Company value calculated using PBV scores between 0.12-9.30 with an average value of 2.4055 and a standard deviation of 2.13789 .

\section{Classic Assumption Test \\ Normality test}

The normality test used in this regression model is a statistical test with nonparametric Kolmogorov-Smirnov (KS). The significance value of residuals are normally distributed is if the value is asymp. Sig (2-tailed) in one-sample Kolmogorov-Smirnov test more than $\alpha=0.05$

Table 3. Normality Test Results

\begin{tabular}{|ll|r|}
\hline & & \multicolumn{2}{|c|}{ Unstandardized Residual } \\
\hline N & Mean & 40 \\
\multirow{2}{*}{ Normal Parameters } & S.b & 4000000 \\
& Std. Deviation & .60656365 \\
Most Extreme $\quad$ Absolute & Positive & .122 \\
Differences & Negatif & .122 \\
Kolmogorov-Smirnov Z & -.089 \\
Astmp. Sig. (2-tailed) & .771 \\
\hline
\end{tabular}

a. Test distribution is Normal.

b. Source: Data processed, 2020

The amount of value Kolmogorov-Smirnov $(K S)$ is 0.591 , which is not significant at $\alpha$ $=0.05$. So, the hypothesis that the abnormal residual data is rejected or, in other words, it can be concluded that the residual model is usually distributed.

\section{Test Multicollinearity}

The tolerance value and VIF in this test are used to detect any multicollinearity problems. Both measures indicate which of each independent variable is explained by other independent variables. If a regression model has a tolerance value $\leq 0.10$ or equal to a VIF value $\geq 10$, then multicollinearity has occurred. Conversely, if a regression model has a tolerance value $\geq 0.10$ or equal to a VIF value $\leq$ ten, then multicollinearity does not happen.

Table 4. Test results Multicollinearity Coefficients

\begin{tabular}{|ll|r|r|}
\hline \multirow{2}{*}{ Model } & \multicolumn{2}{|c|}{ Collinearity Statistics } \\
\cline { 3 - 4 } & & Tolerance & \multicolumn{2}{|c|}{ VIF } \\
\hline \multirow{2}{*}{1} & FO & .850 & 1,176 \\
DER & .831 & 1,203 \\
\hline
\end{tabular}


a. Dependent Variable: PBV

Source: Data processed, 2020

Multicollinearity testing results indicate that the value tolerance of all variables $\geq$ 0.10 and CO VIF values all variables $\leq 10$. This shows that all the variables in this study did not occur multicollinearity with other variables in the model.

\section{Heteroscedasticity Test}

The Glejser test detected heteroscedasticity in this study. Glejser test is detecting the presence or absence of heteroscedasticity by regressing the absolute value of residuals to the independent variables. Decision making regarding heteroscedasticity is if the significance value is more than 0.05 (probability value> 0.05), then it can be concluded that the regression model is free from heteroscedasticity symptoms.

Tabel 5. Heteroscedasticity Test Results Coefficients

\begin{tabular}{|c|c|c|c|c|c|}
\hline \multirow[t]{2}{*}{ Model } & \multicolumn{2}{|c|}{ Unstandardized Coefficients } & \multirow{2}{*}{$\begin{array}{c}\text { Standardized } \\
\text { Coefficients }\end{array}$} & \multirow[t]{2}{*}{$\mathrm{t}$} & \multirow[t]{2}{*}{ Sig. } \\
\hline & B & Std. Error & & & \\
\hline (Constant) & 4.125 & 2.320 & & 1.778 & .084 \\
\hline FO & -.009 & .325 & -.004 & -.029 & 977 \\
\hline DER & .265 & .082 & ,478 & 3.224 & .073 \\
\hline SIZE & -1.816 & 1.199 & -.226 & -1.515 & 139 \\
\hline
\end{tabular}

a. Dependent Variabel: RES_2

Source: Data processed, 2020

Based on the results of heterokedasticity testing above shows that probability valueall variables> 0.05 . This shows that all variables in this study did not contain heteroscedasticity.

Test Autocorrelation

Based on the DW calculation results obtained a number of DW after 1.226 and DW before 1.167 to detect negative autocorrelation then (4-DW) then:

1. DW before: 2,833

2. DW after: 2,774

Based on DW table $\mathrm{n}=40$ and $\mathrm{k}=3$ obtained $\mathrm{DL}=1.33$ and $\mathrm{DU}=1.65$ from this result, the value of $4-\mathrm{DW}=2,774$ is greater than DU so there is no negative autocorrelation. Whereas after the control variable 4-DW value is obtained greater value from DU so there is no negative autocorrelation.

\section{Multiple Regression Analysis}

The results of multiple regression analysis with the control variables obtained the following results:

Table 6. Results of Multiple Regression Analysis Coefficients

\begin{tabular}{|l|c|c|c|c|}
\hline Model & $\begin{array}{c}\text { Unstandardized } \\
\text { Coefficients }\end{array}$ & $\begin{array}{c}\text { Standardized } \\
\text { Coefficients }\end{array}$ & $\mathrm{t}$ & Sig. \\
\hline
\end{tabular}




\begin{tabular}{|l|r|r|r|r|r|}
\hline & \multicolumn{1}{c|}{ B } & Std. Error & Beta & & \\
\hline (Constant) & $-10,378$ & 4,333 & & $-2,395$ & .22 \\
FO & 3,018 & 607 & .505 & 4,969 & .000 \\
DER & -1.187 & .153 & -976 & $-7,737$ & .000 \\
SIZE & $-1,035$ & 2,240 & -.048 & -.462 & .647 \\
\hline
\end{tabular}

a. Dependent Variabel: PBV

Source: Data processed, 2020

Based on Table 6, a regression equation can be formulated to determine the effect (family ownership, debt policy, and company size) on firm value as follows:

$$
\text { PBV = (-10,378) + 3,018 FO + (-1,187) DER + (- 1,035) SIZE }
$$

Table 7. Results of Multiple Regression Analysis Coefficients

\begin{tabular}{|l|r|r|r|r|r|}
\hline \multirow{2}{*}{ Model } & \multicolumn{2}{|c|}{ Unstandardized Coefficients } & \multicolumn{1}{c|}{$\begin{array}{c}\text { Standardized } \\
\text { Coefficients }\end{array}$} & \multirow{2}{*}{ Sig. } \\
\cline { 2 - 5 } & \multicolumn{1}{|c|}{ B } & \multicolumn{1}{c|}{ Std. Error } & Beta & & \\
\hline (Constant) & $-12,039$ & 2,395 & & $-5,026$ & .000 \\
FO & 2,926 & .567 & .490 & 5,157 & .000 \\
DER & -1.162 & .142 & -778 & $-8,198$ & .000 \\
\hline
\end{tabular}

a. Dependent Variabel: PBV

Source: Data processed, 2020

Based on Table 7, a regression equation can be formulated to determine the effect (family ownership and debt policy) on the company's value as follows:

$$
\text { PBV }=(-12,039)+2,926 \text { FO + (-1,162) DER }
$$

\section{Coefficient of Determination}

The coefficient of determination $\left(\mathrm{R}^{2}\right)$ measures how far the model's ability to explain the variation of the dependent variable. The coefficient of determination between zero and one $(0 \leq \mathrm{R} 2 \geq 1)$.

Table 8. Results Coefficient of Determination Summary Model

\begin{tabular}{|l|r|r|r|r|}
\hline Model & \multicolumn{1}{|c|}{$\mathrm{R}$} & R Square & \multicolumn{1}{c|}{$\begin{array}{c}\text { Adjusted R } \\
\text { Square }\end{array}$} & \multicolumn{2}{|c|}{$\begin{array}{c}\text { Std. Error of the } \\
\text { Estimate }\end{array}$} \\
\hline 1 & $.827 \mathrm{a}$ & .684 & .657 & .63133 \\
\hline
\end{tabular}

a. $\quad$ Predictors: (Constant), SIZE, FO, DER

Source: Data processed, 2020

The coefficient of determination shown by $\mathrm{R}^{2}$ shows a number 0.684 , which means that the combination of independent variables such as family ownership, debt policy (DER), and company size as a control variable can explain the dependent variable, namely the company's value of $68.4 \%$.

Table 9. Results Coefficient of Determination Model Summary

\begin{tabular}{|l|l|l|l|l|}
\hline Model & R & R Square & Adjusted R & Std. Error of the \\
\hline
\end{tabular}




\begin{tabular}{|l|r|r|r|rr|}
\hline & & & Square & \multicolumn{2}{|c|}{ Estimate } \\
\hline 1 & $.826 \mathrm{a}$ & .682 & .665 & .62459 \\
\hline
\end{tabular}

a. $\quad$ Predictors: (Constant), DER, FO

Source: Data processed, 2020

The coefficient of determination shown by $\mathrm{R}^{2}$ shows a figure 0.682 , which means that the combination of independent variables such as family ownership and debt policy (DER) can explain the dependent variable, which is the company's value of $68.2 \%$. While the remaining $32.8 \%$ is influenced by other factors.

\section{Hypothesis testing}

F test

F test is used to calculate whether together (simultaneously) existing independent variables affect the dependent variable. The results of the test in the presence of company size as a control variable can be seen in the following table:

Table 10. Test Results F ANOVA

\begin{tabular}{|c|r|r|r|r|r|}
\hline Model & Sum of Squares & \multicolumn{1}{|c|}{ Df } & Mean Square & F & Sig. \\
\hline \multicolumn{1}{|c|}{ Regression } & 31,014 & 3 & 10,338 & 25,937 & $.000 \mathrm{~b}$ \\
Residual & 14,349 & 36 & .399 & & \\
\multicolumn{1}{|c|}{ Total } & 45,362 & 39 & & & \\
\hline
\end{tabular}

a. Dependent Variable: PBV

b. Predictors: (Constant), SIZE, FO, DER

Source: Data processed, 2020

Based on Table 10 shows that the calculated $F$ value of 25.937. This value is greater than the $\mathrm{F}$ table of 2.84 or $\mathrm{F}$ arithmetic $>\mathrm{F}$ table 2.84 with a probability of 0.002 . Because the probability value is much smaller than 0.05 , it can be said that the variable family ownership, debt policy, and company size together have a positive and significant effect on firm value.

Then for F test results without company size as a control variable can be seen in the following table:

Table 11. Test Results F ANOVA

\begin{tabular}{|l|r|r|r|r|r|}
\hline Model & Sum of Squares & Df & Mean Square & F & Sig. \\
\hline \multicolumn{1}{|c|}{ Regression } & 30,928 & 2 & 15,464 & 39,641 & $.000 \mathrm{~b}$ \\
1 Residual & 14,434 & 37 & .390 & & \\
\multicolumn{1}{|c|}{ Total } & 45,362 & 39 & & & \\
\hline
\end{tabular}
a. Dependent Variable: PBV
b. Predictors: (Constant), DER, FO
Source: Data processed, 2020

Based on Table 10 shows that the calculated $\mathrm{F}$ value was 39.641. This value is greater than the $\mathrm{F}$ table which is 3.32 or $\mathrm{F}$ arithmetic $>\mathrm{F}$ table 3.32 with a probability of 
0.002. Because the probability value is much smaller than 0.05 , it can be said that the variable family ownership, debt policy, and company size together have a positive and significant effect on firm value.

T test

$\mathrm{T}$ test results can be viewed probability value. If the probability value $<0.05$, then Ho is rejected or $\mathrm{Ha}$ is accepted (there is a partial effect) and if the probability value> 0.05 , then Ho is accepted or Ha is rejected (there is no partial effect).

Table 12. Test Results $t$ Coefficients

\begin{tabular}{|l|r|r|r|r|r|}
\hline \multirow{2}{*}{ Model } & \multicolumn{2}{|c|}{ Unstandardized Coefficients } & \multicolumn{1}{c|}{$\begin{array}{c}\text { Standardized } \\
\text { Coefficients }\end{array}$} & \multicolumn{1}{c|}{ Sig. } \\
\cline { 2 - 4 } & \multicolumn{1}{|c|}{$\mathrm{B}$} & \multicolumn{1}{c|}{ Std. Error } & \multicolumn{1}{c|}{ Beta } & & \\
\hline \multirow{2}{*}{ (Constant) } & $-10,378$ & 4,333 & & $-2,395$ & .22 \\
FO & 3,018 & 607 & .505 & 4,969 & .000 \\
DER & -1.187 & .153 & -976 & $-7,737$ & .000 \\
SIZE & $-1,035$ & 2,240 & -.048 & -.462 & 647 \\
\hline
\end{tabular}

a. Dependent Variable: PBV

Source: Data processed, 2020

Based on Table 12 shows that the influence of the independent variables on the dependent variable partially can be described as follows:

1. Based on the test results from the above table, it can be seen that the value of $t$ family ownership to the company's value is 4.969 , which is smaller than the $t$ table of 1.68385 with a significant level of 0.000 which is lower than 0.05 . This shows that family ownership has a positive and significant effect on firm value, so it can be concluded that the first hypothesis (H1) Family Ownership considerable effect on company value be accepted.

2. Based on the test results from the above table, it can be seen that the value of the $\mathrm{t}$ policy of debt (DER) to the company's value is $-7,737$, which is higher than 1.68385 with a significant level of 0,000 less than 0.05 . This shows that debt policy has a negative and significant effect on firm value, it can be concluded that the second hypothesis $\left(\mathrm{H}_{2}\right)$ is. The debt policy is thought to have a positive impact on the value of the company received.

3. Based on the test results from the above table, it can be seen that the amount of $t$ size of the company is -.462 smaller than 1.68385 with a significant level647 greater than 0.05. This shows that company size has a negative and not significant effect on firm value, so it can be concluded that the third hypothesis (H3) is Company size as a control variable has a positive impact on rejected company value.

Then for T-test results without company size as a control variable are as follows:

\section{Model 2 Table 13. Test Results $t$ Coefficients}




\begin{tabular}{|l|r|r|r|r|r|}
\hline Model & \multicolumn{2}{|c|}{ Unstandardized Coefficients } & \multicolumn{1}{c|}{$\begin{array}{c}\text { Standardized } \\
\text { Coefficients }\end{array}$} & \multicolumn{1}{c|}{ Sig. } \\
\cline { 2 - 4 } & \multicolumn{1}{|c|}{ B } & Std. Error & \multicolumn{1}{c|}{ Beta } & & \\
\hline (Constant) & $-12,039$ & 2,395 & & $-5,026$ & .000 \\
FO & 2,926 & .567 & .490 & 5,157 & .000 \\
DER & -1.162 & .142 & -778 & $-8,198$ & .000 \\
\hline
\end{tabular}

a. Dependent Variable: PBV

Source: Data processed, 2020

Based on the results of the t-test in the table above shows that the influence of independent variables on the dependent individual can be described as follows:

1. Based on the test results from the above table, it can be seen that the value of $t$ family ownership to the company value is 5,157 which is smaller than the table of 1.68385 with a significant level of 0,000 , which is lower than 0.05 . This shows that family ownership has a positive and significant effect on firm value, so it can be concluded that the first hypothesis $\left(\mathrm{H}_{1}\right)$ Family Ownership considerable effect on company value be accepted.

2. Based on the test results from the above table, it can be seen that the value of the $\mathrm{t}$ policy of debt (DER) to the company's value is --8,198, which is higher than 1.68385 with a significant level of 0,000 less than 0.05 . This shows that debt policy has a negative and significant effect on firm value, so it can be concluded that the second hypothesis $\left(\mathrm{H}_{2}\right)$ is The debt policy is thought to have a positive impact on the value of the company received.

\section{Conclusion and Suggestion}

Family ownership has a positive and significant effect on the value of the company's so that when family ownership increases, it will increase its value. The debt policy calculated by DER has a negative and significant effect on the company's so that its value will increase when the debt policy falls. The size of the company is not able to control the relationship between the influence of family ownership and debt policy on the value of the company. So that when the company's size has increased, the value of the company will not increase.

\section{References}

1) Barney, J. (1991). Firm Resources and Sustained Competitive Advantage. Journal of Management. https://doi.org/10.1177/014920639101700108

2) Beuren, I. M., Politelo, L., \& Martins, J. A. S. (2016). Influence of family ownership on company performance. International Journal of Managerial Finance. https://doi.org/10.1108/IJMF-09-2014-0151

3) Brigham, E. F., \& Houston, J. F. (2014). Dasar-Dasar Manajemen Keuangan: Assetials Of Financial Management. Salemba Empat. https://doi.org/10.1145/2505515.2507827

4) Butje, S., Pahlevi, C., \& Pakki, E. (2019). Pengaruh Keputusan Keuangan terhadap Nilai Perusahaan dengan Profitabilitas sebagai Variabel Moderating. 
Hasanuddin Journal of Applied Business and Entrepreneurship.

5) Connelly, B. L., Certo, S. T., Ireland, R. D., \& Reutzel, C. R. (2011). Signaling theory: A review and assessment. Journal of Management. https://doi.org/10.1177/0149206310388419.

6) Demsetz, H., \& Lehn, K. (2009). The structure of corporate ownership: Causes and consequences. In Readings in Applied Microeconomics: The Power of the Market. https://doi.org/10.4324/9780203878460.

7) Fakhruddin, \& Sopian, H. (2001). Perangkat dan Model Analisis Investasi di Pasar Modal. (Buku satu). Jakarta: Elex Media Komputindo, Jakarta.

8) Fitri Prasetyorini, B. (2013). Pengaruh Ukuran Perusahaan, Leverage, Price Earning Ratio dan Profitabilitas terhadap Nilai Perusahaan. Jurnal Ilmu Manajemen (JIM).

9) Habbash, M. (2016). Corporate governance and corporate social responsibility disclosure: Evidence from Saudi Arabia. Social Responsibility Journal. https://doi.org/10.1108/SRJ-07-2015-0088.

10)Harahap, L., \& Wardhani, R. (2011). Analisis Komprehensif Pengaruh Family Ownership, Masalah Keagenan, Kebijakan Dividen, Kebijakan Hutang, Corporate Governance Dan Opportunity Growth Terhadap Nilai Perusahaan. Simposium Nasional Akuntansi XV.

11)Harmono. (2011). Manajamen Keuangan Berbasis Balanced Scorecard Pendekatan Teori, Kasus, dan Riset Bisnis. In Manajemen Keuanggan.

12)Herawati, T. (2013). Pengaruh Kebijakan Dividen, Kebijakan Hutang Dan Profitabilitas Terhadap Nilai Perusahaan. Jurnal Manajemen.

13) Jensen, N., \& Meckling, W. (1976). Theory of the firm: Managerial behavior, agency costs, and capital structure. Journal of Financial Economics.

14)Litz, R. A., Pearson, A. W., \& Litchfield, S. (2012). Charting the Future of Family Business Research: Perspectives From the Field. Family Business Review. https://doi.org/10.1177/0894486511418489.

15) Mardiyati, U., Gatot, N. A., \& Ria, P. (2012). Pengaruh Kebijakan Dividen, Kebijakan Hutang dan Profitabilitas terhadap Nilai Perusahaan Manufaktur yang Terdaftar di Bursa Efek Indonesia (BEI) Periode 2005-2010. Jurnal Riset Manajemen Sains Indonesia (JRMSI), 3(1).

16) Meythi. (2012). Dampak Interaksi Antara Kebijakan Utang dan Kebijakan Dividen dalam Menilai Perusahaan. Jurnal Keuangan Dan Perbankan.

17)N.A. \& Che-Ahmad, a. A. (2010). Family Succession and Firm Performance among Malaysian Companies. International Journal of Business and Social Science.

18) Nurhayati, M. (2013). Profitabilitas, likuiditas dan ukuran perusahaan pengaruhnya terhadap kebijkan dividen dan nilai perusahaan sektor non jasa. Jurnal Keuangan Dan Bisnis.

19)Pasaribu, U. R., Nuryartono, N., \& Andati, T. (2019). Pengaruh Faktor Internal Dan Eksternal Perusahaan Terhadap Nilai Perusahaan. Jurnal Aplikasi Bisnis Dan Manajemen. https://doi.org/10.17358/jabm.5.3.441.

20)Rizqia, Dwita, A., Siti, A., \& Sumiati. (2013). Effect of Managerial Ownership, Financial Leverage, Profitability, Firm Size, and Investment Opportunity on 
Dividend Policy and Firm Value. Research Journal of Finance and Accounting, 4(11).

21) Warapsari, A., \& Suaryana, I. (2016). Pengaruh Kepemilikan Manajerial Dan Institusional Terhadap Nilai Perusahaan Dengan Kebijakan Utang Sebagai Variabel Intervening. E-Jurnal Akuntansi.

22) Wardhani, R. S., Awaluddin, M., \& Reniati. (2019). Financial Performance and Corporate Social Responsibility on Return of Shares. Jurnal Akuntansi Universitas Tarumanagara, XXIII(03), 409-432.

23) Yuniati, M., Raharjo, K., \& Abrar, O. (2016). Pengaruh Kebijakan Deviden, Kebijakan Hutang Profitabilitas Dan Struktur Kepemilikan Terhadap Nilai Perusahaan Pada Perusahaan Manufaktur Yang Terdaftar Di Bursa Efek Indonesia Periode 2009-2014. Accounting. 